\title{
Vaccination of Quails with Bivalent Inactivated H5N1 AI Vaccine (Clades 2.1.3 and 2.3.2) at Laboratory Scale
}

\author{
Indriani R, Dharmayanti NLPI \\ ${ }^{1}$ Indonesian Research Center for Veterinary Science \\ Jl. RE Martadinata No. 30, Bogor 16114, West Java, Indonesia \\ risain52@yahoo.com
}

\begin{abstract}
Quails, Coturnix sp, are commercially bred for meat and egg production in order to support the needs for animal protein. Cases of H5N1 Avian Influenza still occur sporadically at quail farms. Vaccination become an option as a precaution against possible exposure to H5N1 AI virus. Thirty quails were vaccinated with bivalent inactivated H5N1 AI vaccine (clade 2.1.3 and 2.3.2) and 10 quails were used as control group. The quails were vaccinated with one dose $(0.3 \mathrm{ml})$ per bird intramuscularly at the age of 23 days and booster was done at the age of 45 days. The response after a single vaccination showed that antibody titers were not optimal, but after the booster vaccination the antibody titers showed $4.2 \log 2$ in average against the H5N1 AI antigen of clade 2.1.3 and $3.7 \log 2$ against the antigen of clade 2.3.2. A challenge test with $\mathrm{H} 5 \mathrm{~N} 1$ influenza virus either with clade 2.1 .3 or clade 2.3 .2 indicated a $70 \%$ protection. Nevertheless, viral shedding was detected $\geq 7$ days post-challenge. As conclusion, vaccination with inactivated bivalent vaccine H5N1 AI clades 2.1.3 and 2.3.2 induced antibody that were was not homogenous nor optimal.
\end{abstract}

Key Words: Quails, H5N1 AI Vaccine, Avian Influenza

\section{INTRODUCTION}

Quails (Coturnix sp. Galliformes) are bred commercially for meat and egg production (Lima et al. 2004). Quails are resistant to many diseases, but they are vulnerable to viruses that cause diseases in chickens, especially when reared under poor management conditions (Ratnamohan 1993).

Avian influenza (AI) subtype H5N1 clade 2.1.3 has been present in Indonesia since at the end of 2003. The disease was first reported in ducks in a farm in Central Java Province in 2012 (Wibawa et al. 2012). Clades 2.1.3 and 2.3.2 of AI H5N1 virus are a highly pathogenic and therefore called Highly Pathogenic Avian Influenza (HPAI). The HPAI virus infects many type of birds, including domestic and wild birds like chickens, ducks, muscovy ducks, geese and quails. HPAI cases in quails in some community farms have been identified. However, the cases still occur sporadically. Recently, outbreak of HPAI in March 2015 caused 3,540 quails died (Directorate General of Livestock and Animal Health 2015, www.ditjennak.deptan.go.id). Prevention of HPAI virus attacks in quails at community farms is conducted by implementing strict biosecurity program and H5N1 AI vaccination.

The caurse of HPAI in quails are longer than that in chickens. Consequently, the duration and the number virus shed to the environment are longer and larger (Makarova et al. 2003). Some species of terrestrial birds may play a role in the origin of influenza viruses with pandemic potential. Quails have the right characteristics to serve as an intermediate host of zoonotic transmission of influenza viruses. Alpha 2,3-galactose sialic acid (alpha 2,3-gal) related receptors, and alpha2,6-galactose sialic acid (alpha 2,6-gal) receptor are linked in the quail trachea and the intestines. In the quail trachea, alpha2,3-gal siliac acid receptors present mainly in non-ciliated cells, while alpha2,6-gal sialic acid receptors are localized on the surface of ciliated cells. In the quail intestines, the two types 
of receptors are found on epithelial cells as well as in the crypts. Based on binding test of overlay solid phase showed that both the bird and the human influenza viruses bind plasma membrane on the epithelial cells of the trachea and the intestines of quails (Wan \& Perez 2006). This experiment indicated that receptors are capable of binding influenza viruses from different species. Futhermore, these results were consistent with the idea that quails can provide an environment for the spread of reassortant between avian and human influenza viruses, thereby they might act as a potential an intermediate host (Wan \& Perez 2006).

Vaccination against H5N1 AI has become one of the most important control measure for HPAI in poultry industry since 2004, as a precautionary measure against possible exposure to H5N1 avian influenza virus (Ditjen PKH 2009). However, H5N1 vaccination in quails at community farms has not yet become a routine program (Personal communication with farmer). Due to the circulation of AI virus $\mathrm{H} 5 \mathrm{~N} 1$ clades 2.1.3 and 2.3.2 in Indonesia precautions against both viruses in poultry (quails) are necessary. Studies on bivalent inactivated vaccine of H5N1 AI clades 2.1.3 and 2.3.2 have been carried out on brown quails (Coturnix ypsilophora). The aim of study was to evaluate the effectiveness of the bivalent inactivated vaccine of $\mathrm{H} 5 \mathrm{~N} 1 \mathrm{AI}$ clades 2.1.3 and 2.3.2 in quails.

\section{MATERIAL AND METHODS}

\section{Bivalent inactivated vaccine H5N1 AI}

Bivalent inactivated vaccine $\mathrm{H} 5 \mathrm{~N} 1$ AI clades 2.1.3 and 2.3.2 was prepared from HPAI virus A/Muscovy duck/Banten/BR7/2013 clade 2.3.2 and A/ck/West Java/Pwt-Wij/2006 clade 2.1.3 using the specific pathogen free (SPF) chicken eggs germinated at the age of 11 days (Ditjen PKH 2014; Dharmayanti et al. 2015; Indriani \& Dharmayanti 2011). AI $\mathrm{H} 5 \mathrm{~N} 1$ virus clade 2.3.2 A/Muscovy duck/Banten/BR7/2013 clade 2.3.2 and A/ck/West Java/Pwt-Wij/2006 clade 2.1.3 was inactivated with $\beta$-propiolactone (1:3000) and formulated with the water to oil ratio of $30: 70$ i.e., $30 \%$ of the vaccine virus in phosphate buffer saline (PBS) and 70\% adjuvant of ISA 71VG Montanide ${ }^{\mathrm{TM}}$. Antigen mass in bivalent AI vaccine contains 256 HAU (128 HAU antigen A/Muscovy duck/Banten/ BR7/2013 clade 2.3.2 and 128 HAU A/ck/West Java/Pwt-Wij/2006 clade 2.1.3) per dose.

\section{Challenge viruses}

The HPAI viruses used were A/Duck/Sukoharjo/Bbvw-1428-9/2012 clade 2.3.2 (Wibawa et al. 2012) and A/West Java/Subang-29/2007 clade 2.1.3 (Ditjen PKH 2009).

\section{Research design}

Forty quails age 22 days, obtained from a quail farm in Cianjur Regency, were divided into 2 groups. Group 1 consisted of 30 quails were vaccinated with AI bivalent inactivated vaccine and had 10 quails without vaccination used a control (group 2). The quails were vaccinated with one dose $(0.3 \mathrm{ml}) / \mathrm{bird}$ intramuscularly at the age of 23 days and revaccinated at the age of 45 days, the age before laying. Sera were collected at the age of 22 days (prior to vaccination), aged 45 days (three weeks after the first vaccination), and the age of 57 days (two weeks after the booster). Sera were tested for hemaglutination inhibition (HI) to find out the status of $\mathrm{H} 5$ antibody titers. Furthermore, the quails were vaccinated with the HPAI challenge viruses A/ck/West Java/Subang-29/2007 clade 2.1.3 (Ditjen PKH 2009) and A/Duck/Sukoharjo/Bbvw-1428-9/2012 clade 2.3.2 (Wibawa et al. 
2012). Each group of vaccinated quails consisting of 10 birds was challenged with $10^{5}$ EID50 virus titer (Reed \& Munch 1983) $0.1 \mathrm{ml} / \mathrm{bird}$ intra nasal and each control group consisting of 5 birds in the isolator cage of BSL-3 Modular (ICRVS). The observation of clinical symptoms of morbidity and mortality was done every morning and evening for 14 days. Observation of the challenge virus shedding was done on days 2, 5, 7 and 14 after challenge (Ditjen PKH 2013) by collecting oropharyngeal and cloacal swabs. Furthermore, reisolation test on the challenge viruses were done.

\section{Serology test for hemaglutination inhibition (HI)}

Quail sera were tested for $\mathrm{HI}$ to measure the content of antibody titer against the AI antigen in the experimental quail sera. Sera were tested against HPAI antigen A/Muscave/Banten/BR7/2013 clade 2.3.2 and A/ck/wj/Pwt-Wij/2006 clade 2.1.3. HI test procedure follows the OIE (2012) and Indraini et al. (2004).

\section{Reisolation test of challenge viruses}

This aim of this step was to determine the shedding of challenge virus in the experimental quails. Oropharyngeal and cloacal swab samples in DMEM medium transport containing 500 IU Penicillin-Streptomycin, gentamycin, fungizone and $2 \%$ fetal calf serum were centrifuged at $1000 \mathrm{~g}$ for 10 minutes. Each swab sample was inoculated into the allantoic sac of SPF chicken eggs germinated aged 10 days, 3 eggs/sample. The viruses were isolated in specific pathogenic free (SPF) chicken eggs germinated at the age of 11 days. Each sample/swab was infected into 3 eggs intra-allantoic. The inoculated eggs were then incubated at $37^{\circ} \mathrm{C}$ for 72 hours. Allantoic fluid from the infected eggs were tested against hemaglutination activity (HA), and when the results gave a negative reaction, advanced tracks were then performed in other germinated eggs to a maximum of three tracks to state that the virus isolation was negative (Swayne \& Jackwood 2006).

\section{Statistical analysis}

Data of serum test results (serology) in the form of antibody (HI titer) from serum samples pre and post-vaccination and post-challenge were presented as Geometric mean.

\section{RESULTS AND DISCUSSION}

\section{Potential results of H5N1 bivalent inactivated vaccine in quails}

Quails aged 24 days (grower) were vaccinated with $\mathrm{H} 5 \mathrm{~N} 1$ bivalent inactivated vaccine (clades 2.1.3 and 2.3.2) intramuscularly in the chest muscles, and 21 days (3 weeks) after the vaccination. The results showed antibody titer responses falled into slight to moderate category (Figure 2). The mean antibody titer against $\mathrm{H} 5 \mathrm{~N} 1$ clade 2.1.3 antigen was 1.8 $\log 2$ with confidence interval (CI) 0.64 to 2.95, while against the H5N1 clade 2.3.2 antigen was $1.9 \log 2$ with CI $0.71-3.08$ (Figure 2). After a single vaccination with H5N1 bivalent inactivated vaccine (clades 2.1.3 and 2.3.2) the antibody titer in quails seemed indifferent compared to the specific pathogenic free (SPF) layer chickens vaccinated with H5N1 bivalent inactivated vaccine (clades 2.1.3 and 2.3.2). Three weeks after the vaccination (age 6 weeks of SPF chickens), the individual antibody titer increased sharply with the mean titer of $6.7 \quad \log 2$ and $\mathrm{CI}$ 6.29-7.13 against the AI antigen clade 2.1. 3 
(A/Chicken/West Java/Pwt-Wij/2006) and $6.5 \quad \log 2$ with CI 5.99-7.03 against the H5N1antigen clade 2.3.2 (A/Muscovy duck/Banten/BR7/2013) (Dharmayanti \& Indriani 2015).

Quails were re-vaccinated (booster) at the age of 45 days prior to production with inactivated-H5N1-bivalent vaccine (clades 2.1.3 and 2.3.2). Figure 2 shows the antibody titer increases, namely; with the mean titer of $4.2 \log 2$ and CI 2.6- 5.7 against the H5N1 antigen clade 2.1.3 and 3.7 with CI 1.79-5.60 against the H5N1 antigen clade 2.3.2. The mean antibody titers did not demonstrate antibody titer responses as well as those in SPF layer chickens, when vaccinated with a single $\mathrm{H} 5 \mathrm{~N} 1$ bivalent inactivated vaccine (clades 2.1.3 and 2.3.2) (Dharmayanti \& Indriani 2015).

\section{Response after vaccination with $\mathrm{AI}$ bivalent inactivated vaccine in quails} 95\% CI for the Mean

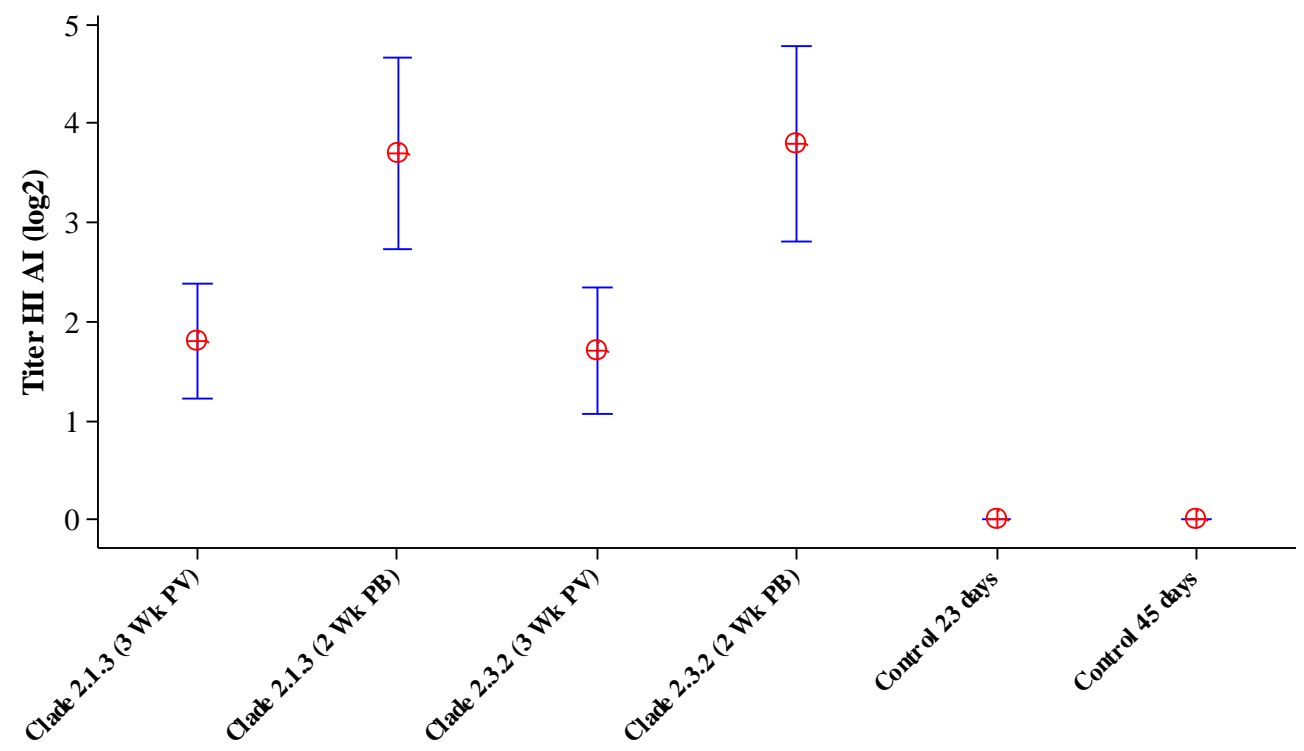

Figure 2. The immune response of quails against H5N1 bivalent inactivated vaccine

The response of quails after vaccination was not as good as the response SPF layer chickens. It might be caused by genetic influences of quails that do not have uniformity in responding to the vaccine. From the quails that received a single vaccination in this study, only $10 \%$ showed a positive antibody titer response against $\mathrm{H} 5 \mathrm{~N} 1$ antigen (data not shown). This finding might indicate that quails were not genetically homogeneous in response to vaccination. Other researchers in Indonesia also carried out $\mathrm{H} 5 \mathrm{~N} 1$ vaccination in quails with replicate treatments (booster), and the result indicated that the positive antibody titer response was less than 50\% (personal communication with other resecher), while in this study the mean positive antibody titer was $70 \%$ in quails vaccinated with booster (Table 1).

Shewita \& Ahmed (2015) in their study explained the provision of phytase supplementation in feed would increase the immune response of quails (Japanese quail) vaccinated with ND and it was significantly different from that of the control quails. ELBagoury et al. (2014) in their study explained that quails vaccinated with Paramyxovirus-1 inactivated vaccine (PPMV-1), responded to the vaccines with a lower hemaglutination inhibition (HI) antibody titers compared to those of pigeons; it could allow the virus to circulate in quails for a long time and increased the virulence that could lead to outbreaks of the disease. 
Table 1. The antibody titer of individuals quail (randomly) prior to challenge against H5N1 AI (clades 2.1.3 and 2.3.2) antigen

\begin{tabular}{|c|c|c|c|c|c|c|c|c|c|c|}
\hline \multicolumn{11}{|c|}{ 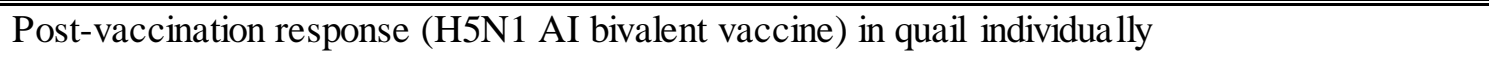 } \\
\hline \multirow{2}{*}{ Gender } & \multirow{2}{*}{ H5N1 Antigen } & \multicolumn{8}{|c|}{ Titer HI AI $(\log 2)$} & \multirow{2}{*}{$\begin{array}{l}\text { Positive } \\
\text { titer (\%) }\end{array}$} \\
\hline & & 0 & 1 & 2 & 3 & 4 & 5 & 6 & 7 & \\
\hline Male & clade 2.1 .3 & $6^{*}$ & 0 & 0 & 0 & 0 & 0 & 0 & 0 & \\
\hline Female & clade 2.1 .3 & 0 & 0 & 0 & 0 & 3 & 7 & 2 & 2 & 70 \\
\hline Male & clade 2.3 .2 & 6 & 0 & 0 & 0 & 0 & 0 & 0 & 0 & \\
\hline Female & clade 2.3 .2 & 0 & 0 & 0 & 0 & 2 & 6 & 4 & 2 & 70 \\
\hline
\end{tabular}

*Number of birds; Positive titer $\geq 4 \log 2$ (OIE 2012)

Takahashi et al. (1984) conducted a breeding selection to obtain a uniform response for ND vaccination with high titers in the quails. The breeding selection is required up to 7 generations. Saad et al. (2010) evaluated the immune response of quails that had AI H5 maternal antibody and were vaccinated with a commercial AI vaccine in Egypt. The results showed that the level of maternal antibody was sufficiently enough until the quails were 7 days and it decreased at age of 10 days. Quails vaccinated at the age of 8 days showed a satisfactory immune response with an mean titer of $6.5 \log 2$ after 3 weeks of vaccination and a titer of $6 \log 2$ was seen continuously for up to 5 weeks after the vaccination (slaughtering age) (Saad et al. 2010). There was no significant difference in the immune response of quails vaccinated with $\mathrm{H} 5 \mathrm{~N} 1$ and $\mathrm{H} 5 \mathrm{~N} 2(\mathrm{P}<0.05)$ (Saad et al. 2010).

Quail aged 57 days (two weeks after the booster vaccination) were challenged with the H5N1 avian influenza virus (A/Duck/Sukoharjo/Bbvw-1428-9/2012 clade 2.3.2 and A/West Java/Subang-29/2007 clade 2.1.3) as shown in Table 2. The quails vaccinated with bivalent inactivated H5N1 AI vaccine (clades 2.1.3 and 2.3.2) showed that 7 out of 10 birds were protected from death, both against exposure to the $\mathrm{H} 5 \mathrm{~N} 1$ avian influenza virus A/Duck/Sukoharjo/Bbvw-1428-9/2012 clade 2.3.2 and virus A/West Java/Subang-29/2007 clade 2.1.3. For the control quails (unvaccinated), mortality occurred in 2.6 days, while in the vaccinated quail group mortality occurred in 3.5 days post-challenge (Table 2). Sarkadi et al. (2013) described in his study on Chinese quails immunized with NIBRG-14 vaccine (clade 1) that the vaccination provided clinical protection and challenge virus shedding after getting a viral infection A/Swan/Nagybaracska/06/01 (H5N1) as much as 10 and 100 particles $\mathrm{LD}_{50}$.

Challenge virus shedding in vaccinated quail groups was visible on day 2 up to day 7 after challenge against AI virus A/West Java/Subang-29/2007 clade 2.1.3, and from day 2 up to day 14 after challenge against virus A/Duck/Sukoharjo/Bbvw-1428-9/2012 clade 2.3.2. This condition was different from SPF layer chickens vaccinated with H5N1 AI bivalent inactivated vaccine (clades 2.1.3 and 2.3.2) and challenged with H5N1 AI virus clade 2.1.3 showing no challenge virus shedding, whereas the challenge with H5N1 AI virus clade 2.3.2, shedding was visible on day 2 (Dharmayanti \& Indriani 2015). This is because the AI H5N1 AI antibody titers of SPF layer chickens after vaccination have outstanding mean antibody titer, namely: $6.7 \log 2$ with CI 6.29-7.13 against the AI antigen clade 2.1.3 and $6.5 \log 2$ with CI 5.99-7.03 against the H5N1 AI antigen clade 2.3.2 (Dharmayanti \& Indriani 2015), whereas quails when challenged had antibody titers of 4.2 
Table 2. Reisolation of challenge viruses

\begin{tabular}{|c|c|c|c|c|c|c|c|c|c|}
\hline \multirow{3}{*}{ Challenge groups } & \multirow{3}{*}{$\begin{array}{l}\text { Mortality } \\
\text { (days) }\end{array}$} & \multicolumn{8}{|c|}{ Reisolation of virus shedding (days post-challenge) } \\
\hline & & \multicolumn{2}{|c|}{2} & \multicolumn{2}{|c|}{5} & \multicolumn{2}{|c|}{7} & \multicolumn{2}{|c|}{14} \\
\hline & & Oropharynx & Cloaca & Oropharynx & Cloaca & Oropharynx & Cloaca & Oropharynx & Cloaca \\
\hline \multicolumn{10}{|l|}{ Clade 2.1.3 } \\
\hline Vaccination & $3 / 10(3.7)^{*}$ & $4 / 10$ & $3 / 10$ & $1 / 8$ & $1 / 8$ & $0 / 7$ & $1 / 7$ & $0 / 7$ & $0 / 7$ \\
\hline Control & $5 / 5(2.8)$ & $10 / 10$ & $10 / 10$ & $\mathrm{NC}$ & $\mathrm{NC}$ & $\mathrm{NC}$ & $\mathrm{NC}$ & $\mathrm{NC}$ & $\mathrm{NC}$ \\
\hline \multicolumn{10}{|l|}{ Clade 2.3.2 } \\
\hline Vaccination & $3 / 10(3.3)^{*}$ & $6 / 10$ & $2 / 10$ & $2 / 8$ & $1 / 8$ & $0 / 7$ & $1 / 7$ & $0 / 7$ & $1 / 7$ \\
\hline Control & $5 / 5(2.4)$ & $10 / 10$ & $10 / 10$ & $\mathrm{NC}$ & $\mathrm{NC}$ & $\mathrm{NC}$ & $\mathrm{NC}$ & $\mathrm{NC}$ & $\mathrm{NC}$ \\
\hline
\end{tabular}

*The mean mortality days; NC: Not conducted 
$\log 2$ with CI 2.6-5.7 against the H5N1 AI antigen clade 2.1.3 and $3.7 \log 2$ with CI 1.795.60 against the $\mathrm{H} 5 \mathrm{~N} 1 \mathrm{AI}$ antigen clade 2.3.2.

Swayne et al. (2014) reported study on H5 AI and $\mathrm{rg}$ AI H5 vaccines that HI antibody titer 8 (3log2) against homologous antigen (vaccine), was difficult to predict the survival from challenge virus infection. While the $\mathrm{HI}$ antibody titer $\geq 32$ against the antigen of the challenge virus, could be predicted to survive from death, and HI antibody titers $\geq 64$ did not secrete a challenge virus two days post-infection. And to have an uniformity response of quail antibody titer could be done by genetic selection through breeding of quails that have a high response after the vaccination (Takahashi et al. 1984).

In this study, vaccination with $\mathrm{H} 5 \mathrm{~N} 1 \mathrm{AI}$ bivalent inactivated vaccine of quails provided $70 \%$ protection from death, after exposure to the $\mathrm{H} 5 \mathrm{~N} 1 \mathrm{AI}$ challenge virus and it was significantly different from the control quails (unvaccinated) $0 \%$. Although quails remained the shedding of the challenge virus, this condition could be combined by implementing biosecurity, namely: spraying disinfectant and restriction of personal entering the farm area (cage).

\section{CONCLUSION}

This study showed that H5N1 AI bivalent inactivated vaccine (clade 2.1.3 and 2.3.2) in quails after revaccination at the age of 24 and 45 days provides significant protection compared to the control quails (unvaccinated). Uniformity response of quail antibody titer could be done by genetic selection through breeding of quails that have a high response after the vaccination.

\section{ACKNOWLEDGEMENT}

The study was carried out using the research funding of the 2015 IRCVS State Budget. Appreciation and acknowledgment are extended to Apipudin and Ali Hamdi as well as all those who helped the realization of this research.

\section{REFERENCES}

Dharmayanti NLPI, Indriani R. 2015. Efikasi vaksin inaktif bivalent avian influenza virus subtipe H5N1 (Clade 2.1.3 dan Clade 2.3.2). J Biol Indonesia. 11:169-176.

Indriani R, Dharmayanti NLPI, Adjid RMA, Darminto. 2011. Potensi virus avian influenza H5N1 isolat A/Ck/West Java/Pwt-Wij/2006 Sebagai Vaksin. J Biol Indonesia. 7:309-320.

Ditjen PKH. 2009. Kebijakan vaksinasi dan dan strategi vaksin avian influenza (AI). No. 30099/PD.620/F/9/2009. Jakarta (Indonesia): Direktorat Jendral Peternakan dan Kesehatan Hewan.

Ditjen PKH. 2014. Rumusan vaksin dan vaksinasi. Semarang 20 Februari 2014. Jakarta (Indonesia): Direktorat Jendral Peternakan dan Kesehatan Hewan.

El-Bagoury GF, El-Habbaa AS, Ahmed BA, Khodeir MH. 2014 Evaluation of quail susceptibility and its role in transmission of pigeon paramyxovirus type 1. Benha Vet Med J. 26:61-70.

Ditjen PKH. 2013. Vaksin influenza inaktif. Farmakope obat hewan Indonesia. Edisi 4. Jakarta (Indonesia): Direktorat Jendral Peternakan dan Kesehatan Hewan. hlm. 69-70.

Lima FS, Santi E, Antonio CP, Luciano DK. (2004). Evaluation of different programs of NDV in Japanese quail. Inter J Poul Sci. 3:23-35. 
Makarova NV, Hiroishi O, Hiroshi K, Webster RG, Daniel RP. 2003. Replication and transmission of influenza viruses in Japanese quail. Virology. 310:8-15.

OIE. 2012. Manual of standards for diagnostic tests and vaccines. Edisi 7. Paris (France): Office International des Epizooties. p. 436-452.

Reed LJ, Munch H. 1983. A simple method of estimating 50 percent end points. Amer J Hyg. 27:493-497.

Swayne DE, Jackwood MJP. 2006. Pathogenicity of avian influenza viruses in poultry. Dev Biol. 124:61-67.

Saad MA, El-hady AI, El-nagar A. 2010. Study on immune response of quail for avian influenza vaccine. J Am Sci. 6:1475-1478.

Swayne DE, Suarez DL, Spackman E, Jadhao S, Dauphin G, Kim M, McGrane J, Weaver J, Daniels P, Indriani R, Yupiana Y, Siregar ES, Prajitno T, Fouchier R, Smith D. 2014. Emergence of antigenically variant Indonesian H5N1 high pathogenicity avian influenza viruses resistant to multiple poultry vaccines. Atlanta (USA): SEPRL (in process).

Shewita RS, Ahmed HA. 2015. Influence of dietary phytase and multiple enzymes supplementations on growth performance, carcass characteristics and immune response in Japanese quail. Am J Life Sci Res. 3:112-127.

Sarkadi J, Jankovics M, Kis Z, Skare J, Fodor K, Gonczol E, Visontai I, Vajo Z, Jankovics I. 2013. Protection of Chinese painted quails (Coturnix chinensis) against a highly pathogenic H5N1 avian influenza virus strain after vaccination. Arch Virol. 158:577-2581. [Internet]. DOI: 10.1007/s00705-013-1754-z PMCID: PMC3830747.

Takahashi S, Inooka S, Mizuma Y. 1984. Selective breeding for high and low antibody responses to inactivated Newcastle disease virus in Japanese quails. Poult Sci. 63:595.

Wan H, Perez DR. 2006. Quail carry sialic acid receptors compatible with binding of avian and human influenza viruses. Virology. 346:278-286.

Wibawa H, Prijono WB, Dharmayanti NLPI, Irianingsih SH, Miswati Y, Rohmah A, Andesyha E, Romlah, Daulay RSD, Safitria K. 2012. Investigasi wabah penyakit pada itik di Jawa Tengah, Yogjakarta dan Jawa Timur: Identifikasi sebuah clade baru virus avian influenza subtype H5N1 di Indonesia. Bul Lab Vet. 12:2-8. 